\title{
Infection of the muscle tissue of the filter-feeding cichlid, Chaetobranchopsis orbicularis Steindachner, 1875, by Kudoa orbicularis (Myxozoa: Multivalvulidae) on Marajó Island in the Brazilian Amazon region
}

[Infeç̧ão por Kudoa orbicularis (Myxozoa: Multivalvulidae) na musculatura de Chaetobranchopsis orbicularis Steindachner, 1875, oriundo da Ilha de Marajó na região Amazônica do Brasil]

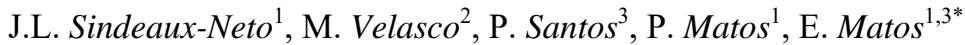 \\ ${ }^{1}$ Programa de pós-graduação - PPGBAIP-UFPA - Belém, Pará \\ ${ }^{2}$ Universidade Federal Rural da Amazônia - UFRA - Campus Tomé Açu, Pará \\ ${ }^{3}$ Laboratório de Pesquisa Carlos Azevedo - LPCA-UFRA - Belém, Pará
}

\begin{abstract}
This study describes aspects of infections caused by the myxosporidian Kudoa orbicularis in filter-feeding cichlids, Chaetobranchopsis orbicularis, caught in the Arari River in the municipality of Cachoeira do Arari, on Marajó Island, Pará, Brazil. The parasite forms pseudocysts scattered throughout the striated epaxial and hypaxial muscles. Samples embedded in paraffin were analyzed histologically using hematoxylin-eosin, Gömöri, Ziehl-Neelsen, and Giemsa staining. Necropsy of the C. orbicularis specimens revealed that $100 \%$ $(50 / 50)$ were infected with K. orbicularis. The specimens presented grossly abnormal muscle texture, resulting in extensive inconsistencies and weakness. Progressive softening of the muscles was observed during necropsy, indicating the rapid enzymatic autolysis of the tissue. The parasite found in the muscle tissue of $C$. orbicularis was identified as K. orbicularis, with clinical signs of disease being observed in the fish. The necropsy revealed extensive damage to the host organism, with well-established fibrocystic infections in the muscle fibers, associated with post mortem myoliquefaction.
\end{abstract}

Keywords: muscle, Kudoa, Myoliquefaction, filter-feeding cichlid, Myxozoa

\section{RESUMO}

O presente estudo descreve os aspectos histopatológicos de infecção causada por mixosporídio da espécie Kudoa orbicularis, o qual forma pseudocistos dispersos em toda a musculatura estriada esquelética, epi e hipoaxial, de Chaetobranchopsis orbicularis, capturados no Rio Arari, município de Cachoeira do Arari, Ilha do Marajó, Pará. Foram realizadas as técnicas histológicas de impregnação em parafina, utilizando-se as colorações de hematoxilina-eosina, Gomori, Ziehl-Neelsen e Giemsa. As análises necroscópicas dos espécimes de C. orbicularis revelaram 100\% (50/50) de infecção por K. orbicularis. Os espécimes apresentavam macroscopicamente musculatura com características anormais de textura, se mostrava inconsistente e frágil. Durante a necropsia, pôde ser observado um progressivo amolecimento da musculatura, o que demonstra um rápido processo enzimático autolítico. Com base nos achados descritos neste trabalho, caracterizou-se uma infecção da musculatura de C. orbicularis por K.orbicularis, com demonstração de sinais clínicos de doença no peixe; os achados necroscópicos mostraram danos ao organismo hospedeiro, com instalação de infecção fibrosística nas fibras musculares, associada com uma mioliquefação post mortem.

Palavras-chave: músculo, Kudoa, mioliquefação, cará, Myхozoa

\section{INTRODUCTION}

The rivers of the Amazon basin contain the world's most diverse freshwater fish fauna in the world, with more than 1500 species described to date (Montag et al., 2008). This fauna includes
20 genera and 100 species of cichlids, approximately $6.7 \%$ of the total. One of these cichlid genera is Chaetobranchopsis, species of which are widely appreciated by aquarium enthusiasts due to the beauty of their coloring and reproductive displays (Kullander, 2003; Lowe-McConnell, 1991).

Recebido em 8 de maio de 2016

Aceito em 4 de janeiro de 2017

* Autor para correspondência (corresponding author)

E-mail: edilson.matos9@gmail.com 
Parasites are the main cause of the loss of economic value in fish and their products. These losses are accentuated in the Neotropics, where the local climate favors the rapid and constant propagation of these organisms (Thatcher and Brites-Neto, 1994). The members of the phylum Myxozoa are a prominent group of fish parasites, and include more than 2200 species, representing 65 genera. These parasites are found as microscopic spores in the tissue of many different vertebrate organs. Myxozoans are the causative agents of diseases that affect both freshwater and marine fish, resulting in high mortality rates in many different regions (Lom and Dykova 2006, Azevedo et al., 2009).

The genus Kudoa is part of the Myxozoa group, which includes a number of potentially important species of parasites that have extremely negative impacts on the quality of fish products. In particular, the species of this genus are responsible for post mortem myoliquefaction, which renders the meat unacceptable for human consumption. The lysis of the muscle tissue results from the production of proteases by the parasites, which depolymerize the host muscle fibers, and facilitate the access of the parasite to other hosts involved in its life cycle. Although these parasites cause diseases in fish, most studies have found no evidence of any risk to human health (Alvarez-Pellitero \& SitjaBobadilla, 1993; Mazorra-Manzano et al., 2008), Kawai et al. (2012) reported poisoning in people who consumed sushi prepared from Paralichthys olivaceus that contained spores of Kudoa septempunctata.

Kudoa is a myxosporidian genus of the order Multivalvulida, which has four or more valves with radial symmetry and quadrangular spores, when observed apically. The suture lines form an angle of $90^{\circ}$. A few species have short apical microvilli with polar capsules that are either essentially the same size or of different sizes (Eiras, 1994). Here, we describe the infection of the tissue of the skeletal muscles of $C$. orbicularis by $K$. orbicularis, including its pathological features and post mortem myoliquefaction.

\section{MATERIALS AND METHODS}

For the present study, 50 specimens of $C$. orbicularis were caught in the Arari River in the municipality of Cachoeira do Arari, on Marajó Island in the state of Pará, Brazil ( $1^{\circ} 00^{\prime} \mathrm{S}, 48^{\circ} 57^{\prime}$ $\mathrm{W})$, between 2014 and 2015. The specimens were transported alive in aerated plastic bags filled with water initially to the town of Salvaterra, and subsequently to the Carlos Azevedo Research Laboratory of the Federal Rural University of the Amazon Region (UFRA), in Belém, where they were kept in an aquarium with a water temperature of $28-30^{\circ} \mathrm{C}$. The fish were anesthetized using tricaine methanesulfonate (MS222; Sigma) at a concentration of $50 \mathrm{mg} / \mathrm{L}$ and were dissected and examined for the presence of parasites and cysts under a stereomicroscope (ethics committee on use of animals $n^{\circ} 013 / 2014$ - UFRA). After the confirmation of the presence of these parasites in muscle tissues, images were captured, and the spores were measured. Small pieces of tissue were removed for observation under an optical microscope. These samples were placed on slides and fixed in place with a coverslip for examination.

When myxozoan parasites were detected, small fragments (approximately $0.5 \mathrm{~cm}$ thick) of the epaxial or hypaxial muscle of the specimen were extracted and fixed in Davidson's solution (neutral buffered formalin, glacial acetic acid and $95 \%$ ethanol in distilled water) for $24 \mathrm{~h}$. The fragments were then processed for embedding in paraffin. Sections of $05 \mu \mathrm{m}$ in thickness were cut from the paraffin block and stained with hematoxylin and eosin, Gömöri, Ziehl-Neelsen and Giemsa (Luna, 1968). These sections were photographed.

For scanning electron microscopy (SEM), spores were fixed in 5\% glutaraldehyde buffered with sodium cacodylate $(\mathrm{pH} 7.2)$ for 12 hours at $4{ }^{\circ} \mathrm{C}$, and then washed overnight in the same buffer solution and post-fixed in $2 \% \mathrm{OsO}_{4}$, buffered with the same solution for 3 hours at $4{ }^{\circ} \mathrm{C}$. The samples were then dehydrated in an increasing series of ethanol. The spores were dried to the critical point, metalized with a fine $(20 \mathrm{~nm})$ layer of gold, and photographed. The specimens were also photographed in a Hitachi TM 3000 Tabletop electron microscope (Hitachi TM 
Infection of the muscle...

3000), for which they were prepared by the same procedure, but were not metallized.

\section{RESULTS AND DISCUSSION}

The analyses identified pseudocysts interspersed between and within the muscle fibers of the epaxial and hypaxial regions. These cysts were filled with mature spores characterized by pseudo-quadratic radial four-valve symmetry and the presence of a polar capsule valve, which are diagnostic of the genus Kudoa (Fig. 1). The necropsy of the $50 \mathrm{C}$. orbicularis specimens revealed that all (100\%) individuals were infected with Kudoa parasites, in all cases, with pseudocysts interspersed both between and within the muscle fibers.
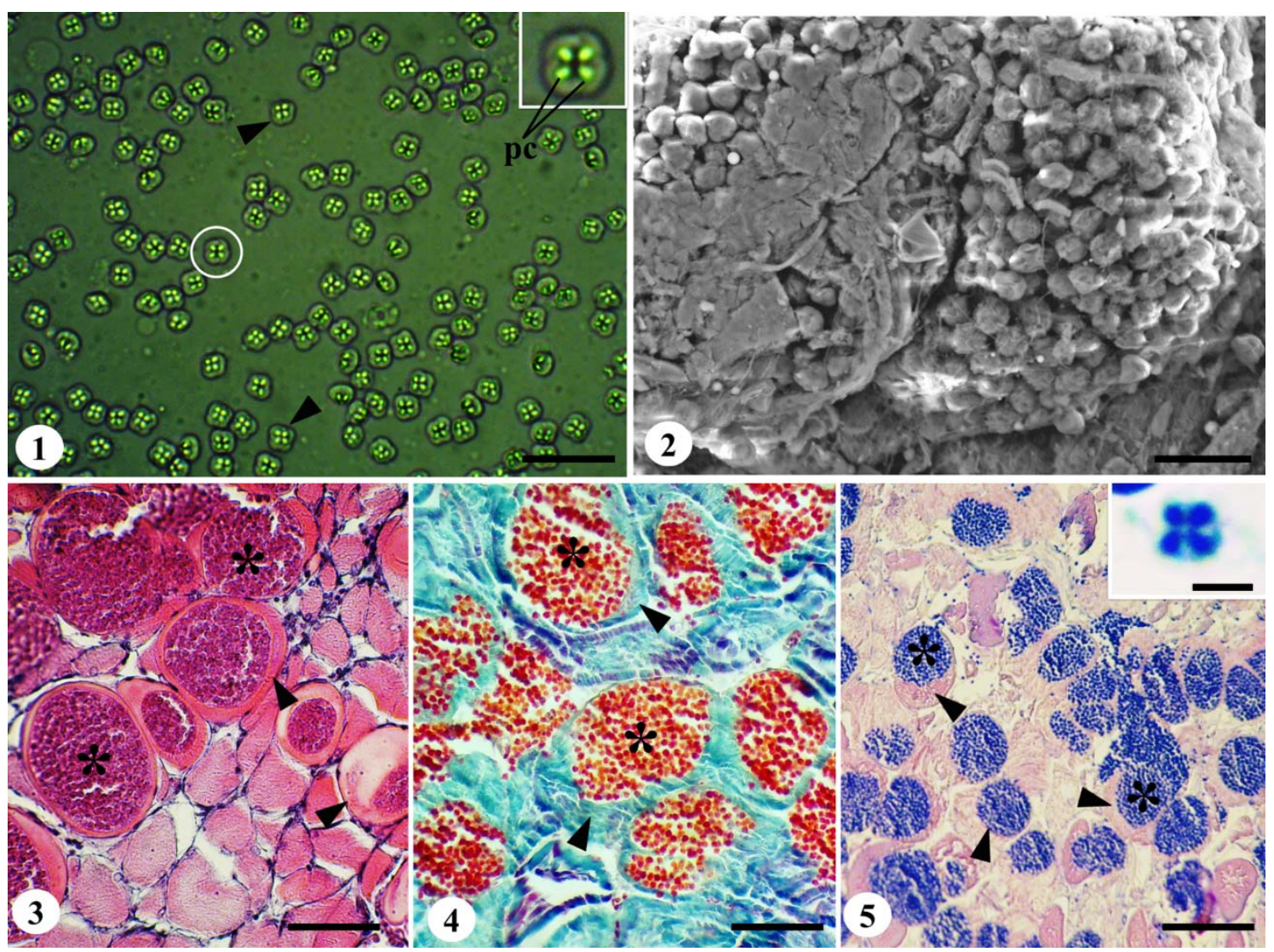

Figure 1. Photomicrograph of a tissue sample from Chaetobranchopsis orbicularis showing fresh Kudoa sp. spores (arrowhead), highlighting the polar capsules (pc); scale bar: $20 \mu \mathrm{m}$. Figure 2: Spores of Kudoa sp. in pseudocysts revealed by Scanning Electron Microscopy; scale bar: $20 \mu \mathrm{m}$. Figure 3, 4 and 5: Histological sections of skeletal striated muscle with pseudocysts $\left(^{*}\right)$ located in the cytoplasm of the fibers (arrowhead), under hematoxylin-eosin, Gömöri and Ziehl-Neelsen staining, respectively; scale bars: $75 \mu \mathrm{m}, 60 \mu \mathrm{m}$ and $160 \mu \mathrm{m}$ respectively. Inset: Spore of Kudoa sp. stained with Giemsa, especially in the four polar capsules; scale bar: $5 \mu \mathrm{m}$.

The infected specimens had grossly abnormal muscle texture with fragile tissue and inconsistent features. Progressive softening of the muscles was observed during necropsy, indicating rapid enzymatic autolysis, as noted by Henning et al. (2013) in specimens infected by Kudoa, who identified the rapid softening of the muscle, which led to post mortem myoliquefaction, as an enzymatic process. However, Andrada et al. (2005) and Azevedo et al. (2016) did not observe any evidence of myoliquefaction in the specimens they examined.

The analysis of the images captured of the fresh Kudoa spores permitted the establishment of morphometric parameters on the length and 
width of the spore and the polar capsule. The parameters recorded in the present study were different from those obtained by Casal et al. (2008) for the spores of Kudoa aequidens found in Aequidens plagiozonatus from a region of the Brazilian Amazon close to the site of the present study, although they were similar to the values obtained by Egusa and Nakajima (1980) for Kudoa amamiensis infecting the Japanese fish Abudefduf sexfasciatus, A. vagiensis, Chromis isharai, C. notatus, Chrysiptera assimilis and Seriola quinqueradiata, and those reported by Dykova et al (2002) for Kudoa dianae found in Sphoeroides annulatus in Mexico. These comparisons indicate that spore size is not necessarily related to the geographic distribution of the parasites (Table 1). The general aspects of the morphology of these parasites are similar to those described in the reviews of Moran et al. (1999a) and Lom and Dykova (2006).

Table 1. Comparison of shape and measurements of spores species of Kudoa sp

\begin{tabular}{|c|c|c|c|c|}
\hline & $\begin{array}{l}\text { Kudoa aequidens } \\
\text { (Casal, 2008) }\end{array}$ & $\begin{array}{c}\text { Kudoa amamiensis } \\
\text { (Egusa \& } \\
\text { Nakajima, 1980) }\end{array}$ & $\begin{array}{c}\text { Kudoa dianae } \\
\text { (Dyková, Avila e Fiala, } \\
\text { 2002) }\end{array}$ & $\begin{array}{l}\text { Kudoa sp. } \\
\text { Present study }\end{array}$ \\
\hline Host & $\begin{array}{c}\text { Aequidens } \\
\text { plagiozonatus }\end{array}$ & $\begin{array}{c}\text { Seriola } \\
\text { quinqueradiata }\end{array}$ & Sphoeroides annulatus & $\begin{array}{c}\text { Chaetobranchopsis } \\
\text { orbicularis }\end{array}$ \\
\hline location & $\begin{array}{l}\text { In sub-opercular } \\
\text { skeletal } \\
\text { musculature }\end{array}$ & $\begin{array}{c}\text { Skeletal } \\
\text { musculature }\end{array}$ & $\begin{array}{c}\text { In extramuscular sites, in } \\
\text { the wall of oesophagus, } \\
\text { and } \\
\text { less frequently on } \\
\text { mesenteries }\end{array}$ & $\begin{array}{l}\text { Epi e Hipoaxial in } \\
\text { skeletal musculature }\end{array}$ \\
\hline PCs & 4 equal size & 4 equal size & 4 equal size & 4 equal size \\
\hline Length & $2.9-3.5$ & $4.5-5.0$ & $4.5-5.5$ & $4.4-4.8$ \\
\hline Width & $6.2-7.1$ & $5.0-6.0$ & $5.5-6.5$ & $5.0-5.6$ \\
\hline $\begin{array}{l}\text { Spore } \\
\text { shape } \\
\text { Polar }\end{array}$ & $\begin{array}{c}\text { Quadrate or } \\
\text { pseudoquadrate }\end{array}$ & Quadrangular & Quadrate & pseudoquadrate \\
\hline $\begin{array}{l}\text { Capsule } \\
\text { (length x } \\
\text { width) }\end{array}$ & $2.0-2.6 \times 1.1-1.5$ & $1.5-2.0 \times 1.0-1.2$ & $2.0 \times 1.5$ & $1.4-2.0 \times 1.2-1.6$ \\
\hline Country & Brazil & Japan & Mexico & Brazil \\
\hline
\end{tabular}

The morphology and morphometry of the spores, the host (C. orbicularis), the site of infection, and the region in which the specimens were collected, all indicate conclusively that the Kudoa species found in the present study was Kudoa orbicularis (Azevedo et al., 2016). The presence of the polar capsules was accentuated clearly by the Giemsa staining of the sections obtained from fragments of infected muscle (Figure 6). This technique was also used successfully by Meng et al. (2011) in an analysis of the polar capsules of Kudoa prunusi.

The SEM (Scanning Electron Microscopy) and histological techniques based on hematoxylineosin (HE), Gomori and Ziehl-Neelsen staining (Figures. 2, 3, 4 and 5) showed the relationship between pseudocysts in the muscle fiber and their spores, with the spores being located both inside and between the muscle fibers, as observed by Moran et al. (1999b) in the infection of Atlantic salmon by Kudoa thyrsites.

The histological-pathological analysis of the infected samples found multifocal necrosis with the presence of fibroblastic tissue adjacent to the pseudocyst regions, together with muscle fibers of irregular appearance, with pyknotic nuclei or a complete absence of the nucleus, and the presence of "tracery" in the sarcoplasm, which is diagnostic of a process of tissue necrosis. Morado and Sparks (1986) described a similar inflammatory process in the muscles of Merluccius productus, caused by Kudoa thyrsites and Kudoa paniformis, which progressed to fibroblastic encapsulation, like that observed in the present study. The hosts analyzed in the present study also appeared apathetic, with lethargic movements, like those observed by 
Azevedo et al. (2016) in Chaetobranchopsis orbicularis infected by Kudoa orbicularis.

The histopathological findings of the present study were consistent with the infection of the muscles of C. orbicularis by Kudoa orbicularis, with clear evidence of clinical disease in the fish specimens. The necropsy revealed extensive damage to the host organism, with fibrocystic infections established in the muscle fibers, resulting in post mortem myoliquefaction.

\section{ACKNOWLEDGMENTS}

We are grateful to Coordenação de Aperfeiçoamento de Pessoal de Nível Superior (CAPES PVE n ${ }^{\circ} 88881.064967 / 2014-01$ ), Conselho Nacional de Desenvolvimento Científico e Tecnológico (CNPq Universal $\mathrm{n}^{\circ}$ 441645/2014-3 and Bolsa de Produtividade em Pesquisa $\left.\quad n^{0} \quad 301497 / 2016-8\right), \quad$ Fundação Amazônia Paraense de Amparo à Pesquisa (FAPESPA ICAAF 162/2014).

\section{REFERENCES}

ALVAREZ-PELLITERO, P.; SITJA-BOBADILLA, A. Pathology of Myxosporea in marine fish culture. Dis. Aquat. Organ., v.17, p.229-238, 1993.

ANDRADA, C.D.G.; TORTELLY, R.; NOGUEIRA, P.P. et al. Infecção por Kudoa meglitsch, 1947 (Myxozoa:Multivalvulida) em musculatura esquelética de espada Trichiurus lepturus L. (Teleostei: Trichiuridae) Parasitol. Latinoam., v.60, p.150-153, 2005.

AZEVEDO, C.; CASAL, G.; MENDONÇA, I.; MATOS, E. Fine structure of Henneguya hemiodopsis sp. n. (Myxozoa), a parasite of the gills of the Brazilian teleostean fish Hemiodopsis microlepes (Hemiodontidae). Mem. Inst. Oswaldo Cruz, v.104, p.975-979, 2009.

AZEVEDO, C.; ROCHA, S.; MATOS, E. et al. Ultrastructural and Phylogenetic Description of Kudoa orbicularis n. sp. (Myxosporea: Multivalvulida): A Parasite Infecting the Muscle of the Fish Chaetobranchopsis orbicularis (Teleostei: Cichlidae) in the Amazon Region $J$. Euk. Microbiol. v.63, p27-36, 2016.
CASAL, G.; MATOS, E.; MATOS, P.; AZEVEDO, C. Ultrastructural Description of a New Myxosporean Parasite Kudoa aequidens sp. n. (Myxozoa, Myxosporea), found in the SubOpercular Musculature of Aequidens plagiozonatus (Teleostei) from the Amazon River. Acta Protozool., v.47, p.135-141, 2008.

DYKOVÁ, I.; AVILA, E.J.F.; FIALA, I. Kudoa dianae sp. n. (Myxosporea: Multivalvulida), a new parasite of bullseye puffer, Sphoeroides annulatus (Tetraodontiformes: Tetraodontidae). Folia Parasitol., v.49, p.17-23, 2002.

EGUSA, S.; NAKAJIMA, K. Kudoa amamiensis n. sp. (Myxosporea: Multivalvulida) found in cultured yellow- tails and wild damselfishes from Amami-Ohshima and Okinawa, Japan. Bull. Jap. Soc. Sci. Fish., v.46, p.1193-1198, 1980.

EIRAS, J.C. Elementos de Ictioparasitologia. Porto: Fundação Engenheiro Antonio de Almeida, 1994. 339p.

HENNING, S.S.; HOFFMAN, L.C.; MANLEY, M. A review of Kudoa - induced myoliquefaction of marine fish species in South Africa and other countries, S. Afr. J. Sci., v.109, p.2-5, 2013

KAWAI, T.; SEKIZUKA, T.; YAHATA, Y. et al. Identification of Kudoa septempunctata as the Causative Agent of Novel Food Poisoning Outbreaks in Japan by Consumption of Paralichthys olivaceus in Raw Fish. Clin. Infect. Dis., v.54, p.1046-1052, 2012.

KULLANDER, S.O. Cichlidae (Cichlids). In REIS, R.E.; KULLANDER, S.O.; FERRARIS JR., C.J. (Eds.). Checklist of the Freshwater Fishes of South and Central America. Porto Alegre: EDIPUCRS, 2003. p.605-654.

LOM, J.; DYKOVÁ, I. Myxozoan genera: definition and notes on taxonomy, life-cycle terminology and pathogenic species. Folia Parasit., v.43, p.1-36, 2006.

LOWE-McCONNELL, R.H. Ecology of cichlids in South American and African waters, excluding the African Great Lakes. In: Cichlids fishes, behavior, ecology and evolution. Miles Keenleyside. Fish Fish. S.2, p.61-70, 1991.

LUNA, L.G. Manual of histologic staining methods of the Armed Forces Institute of Pathology. 3.ed. New York: MacGraw-Hill Book Company, 1968. 258p. 
MAZORRA-MANZANO, M.A.; PACHECOAGUILAR, R.; RAMÍIREZ-SUÁREZ, J.C.; GARCÍA-SÁNCHEZ， G. Pacific whiting (Merluccius productus) underutilization in the Gulf of California: Muscle autolytic activity characterization. Food Chem., v.207, p.106-111, 2008.

MENG, F.; YOKOYAMA, H.; SHIRAKASHI, S. et al. Kudoa prunusi n. sp. (Myxozoa: Multivalvulida) from the brain of Pacific bluefin tuna Thunnus orientalis (Temminck \& Schlegel, 1844) cultured in Japan. Parasitol. Internat., v.60, p.90-96, 2011.

MONTAG, L.F.A.I.; FREITAS, T.M.S.; WOSIACKI, W.B.; BARTHEM, R.B. Os peixes da Floresta Nacional de Caxiuanã (municípios de Melgaço e Portel, Pará - Brasil). Bol. Mus. Para. Emilio Goeldi Cienc. Nat. v.3, p.11-34, 2008.

MORADO, J.F.; SPARKS, A. Observations on the host-parasite relations of the Pacific whiting, Merluccius productus (Ayres), and two myxosporean parasites, Kudoa thyrsitis (Gilchrist, 1924) and K. paniformis Kabata \& Whitaker, 1981. J. Fish Dis., v.9, p.445-455, 1986.
MORAN, J.D.W.; WHITAKER, D.J.; KENT, M.L. A review of the myxosporean genus Kudoa Meglitsch, 1947, and its impact on the international aquaculture industry and commercial fisheries. Aquaculture, v.172, p.163196, 1999a.

MORAN, J.D.W; MARGOLIS, L.; WEBSTER, J.M.; KENT, M.L. Development of Kudoa thyrsites (Myxozoa: Myxosporea) in netpenreared Atlantic salmon determined by light microscopy and a polymerase chain reaction test. Dis. Aquat. Org., v.37, p.185-193, 1999b.

THATCHER, V.E.; BRITES-NETO. Diagnóstico, prevenção e tratamento das enfermidades de peixes neotropicais de água doce. Rev. Bras. Med. Vet., v.16, p.111-128, 1994. 